\title{
Osteological Development of the Larvae and Juvenile of Favonigobius gymnauchen (Pisces:Gobiidae)
}

\author{
Dong-Soo Jin' ${ }^{1}$, Jae-Min Park ${ }^{2}$, Jeong-lk Baek ${ }^{3}$, and ${ }^{\dagger}$ Kyeong-Ho Han ${ }^{4}$ \\ ${ }^{1}$ Research Center for Freshwater Fishes, Miryang 50411, Korea \\ ${ }^{2}$ Native Fish Business Center, Uiseong 37366, Korea \\ ${ }^{3}$ Fisheries Resources Research Center, National Institute of Fisheries Sciences, Tongyeong 56034, Korea \\ ${ }^{4}$ Fishery Science, Chonnam National University, Yeosu 59626, Korea
}

\section{Abstract}

This study was carried out to observe the development of the autonomous skeletal development of the Favonigobius gymnauchen. Total length (TL) of larvae 3 days after hatching (DAH) were mean TL of $3.34 \mathrm{~mm}$, with a line-shaped parasphenoid ossification in the cranium and basioccipital ossification in the back. The $10 \mathrm{DAH}$ larvae had a mean TL of $5.20 \mathrm{~mm}$, with the number of caudal vertebrae increasing to 15 . The urostyle and two hypural bones in the lower part also began to ossify. The $23 \mathrm{DAH}$ juveniles had a mean TL of 8.47 $\mathrm{mm}$. The pectoral girdle's skeleton was completed as the scapula and coracoid were ossified. The pelvic girdle also fully supported the ventral fin as its ossification was completed. Favonigobius gymnauchen and Tridentiger obscurus showed similar characteristics in terms of the anus location of hatched larvae, number of myotomes, and melanophore distribution during the morphological development of the larvae and juveniles. However, this study confirmed differences in the development of the vertebrae and urostyle bone.

Keywords: Favonigobius gymnauchen, Gobiidae, Juvenile, Larvae, Osteological, Skeleton

\section{INTRODUCTION}

There are 189 genera and 1,395 species of Gobiidae fish (order Perciformes) worldwide, with 19 genera and 39 species reported in South Korea (Nelson et al., 2016).

Favonigobius gymnauchen is a fish species belonging to the Gobiidae genus Favonigobius and is distributed around Jeju Island, the West and South Sea coasts and estuaries in South Korea, and China, Japan, and the Western Pacific (Chae et al., 2019).

Studies on F. gymnauchen include its ecology, feeding habits (Huh \& Kwak, 1998), histology (Kim et al., 2016), reproductive cycles (Lee et al., 2000), spawning behavior, and morphological development of eggs, larvae, and juveniles (Jin et al., 2003).

Studies of the skeletons of Gobiidae fish cover Chaenogobius laevis (Kim \& Han, 1989), Periophthalmus modestus (Lee, 1990), Luciogobius guttatus (Kim et al., 1992), L. grandis (Yun et al., 2020), Tridentiger obscurus (Hwang et al., 2018), and T. trigonocephalus (Han et al., 2018).

Studies of the skeletal development of larvae and juveniles handle the systematic basic traits of the young stage (Mook, 1977; Potthoff et al., 1987, 1988; Potthoff \& Tellock, 1993; Liu, 2001; Sfakianakis 
Ethics approval

This article does not require IRB/IACUC approval because there are no human and animal participants. et al., 2004; Çoban et al., 2009). These studies also provide important data for species identification and the skeleton characteristics of broodstock. Hence, the specific and systematic study of $F$. gymnauchen is also required (Koumoundouros et al., 1997a, b).

Many Gobiidae fishes, including F. gymnauchen, coexist and reproduce in coastal estuaries and brackish waters where freshwater and seawater meet. This can make it difficult to identify the larvae and juveniles of these species, which often have similar external morphological characteristics. Systematic research data are needed to identify interspecies differences during the larval and juvenile periods. Therefore, the aim of this study was to observe the skeletal development of larval and juvenile F. gymnauchen inhabiting South Korea and compare it with other Gobiidae fish species to provide basic data for systematic research.

\section{MATERIALS AND METHODS}

Specimens were obtained using the larval and juvenile samples of Jin et al. (2003), which were stained with Walker \& Kimmel's staining method (2007), and preserved in $\mathrm{KOH} 0.1 \%$ and glycerol $50 \%$. After the staining was completed, the larvae and juveniles were observed, and sketches were drawn for each part using a stereoscopic microscope (SMZ800, Nikon, Tokyo, Japan). The name of each part of the skeleton was given in accordance with Han et al. (2018).

\section{RESULTS}

\section{Cranium and viscera}

The total length (TL) of larvae 3 days after hatching (DAH) were 3.28 to $3.45 \mathrm{~mm}$ (mean $3.34 \pm 0.12 \mathrm{~mm}, \mathrm{n}=10$ ), with a line-shaped parasphenoid ossification in the cranium and basioccipital ossification in the back. The premaxillary and maxillary bones were ossified in the upper jaw, and the dentary bone was ossified in the lower jaw. The hyomandibular and endopterygoid in the palate and ceratohyal and epihyal in the hyoid arch were ossified (Fig. 1A).

The TL of 5 DAH larvae were 3.81 to $4.07 \mathrm{~mm}$ (mean $3.96 \pm 0.18 \mathrm{~mm}, \mathrm{n}=10$ ), with frontal ossification in the cranium. The metapterygoid in the palate and preopercle and opercle in the opercular were ossified. The articular in the lower jaw and the hypohyal in the hyoid arch were also ossified (Fig. 1B)

The TL of 10 DAH larvae were 5.12 to $5.24 \mathrm{~mm}$ (mean $5.15 \pm 0.08 \mathrm{~mm}, \mathrm{n}=10$ ), and the pterotic, epiotic, exoccipital, prefrontal, and supraoccipital in the cranium were ossified. The subopercle and interopercle in the opercular, and the angular in the lower jaw were ossified. The glossohyal and four branchiostegal rays in the hyoid arch, and the ectopterygoid and quadrate in the palate were also ossified (Fig. 1C).

The TL of 15 DAH larvae were 6.17 to $6.31 \mathrm{~mm}$ (mean $6.21 \pm 0.09 \mathrm{~mm}, \mathrm{n}=10$ ). The opisthotic, alisphenoid, and nasal were ossified in the cranium, while the palatine in the palate and the six branchiostegal rays in the hyoid arch were all ossified (Fig. 1D).

The TL of $23 \mathrm{DAH}$ larvae were 8.69 to $9.10 \mathrm{~mm}$ (mean $8.87 \pm 0.28 \mathrm{~mm}, \mathrm{n}=10$ ), with ossifications of the prootic, vomer, and ethmoid in the cranium. In the hyoid arch, the urohyal and interhyal were ossified, and the symplectic was ossified in the palate (Fig. 1E).

The TL of $29 \mathrm{DAH}$ juveniles were 9.98 to $10.5 \mathrm{~mm}$ (mean $10.2 \pm 0.36 \mathrm{~mm}, \mathrm{n}=10$ ), and the ossification of the cranium and visceral skeleton was completed by ossifying the sphenotic in the cranium (Fig. 1F). 

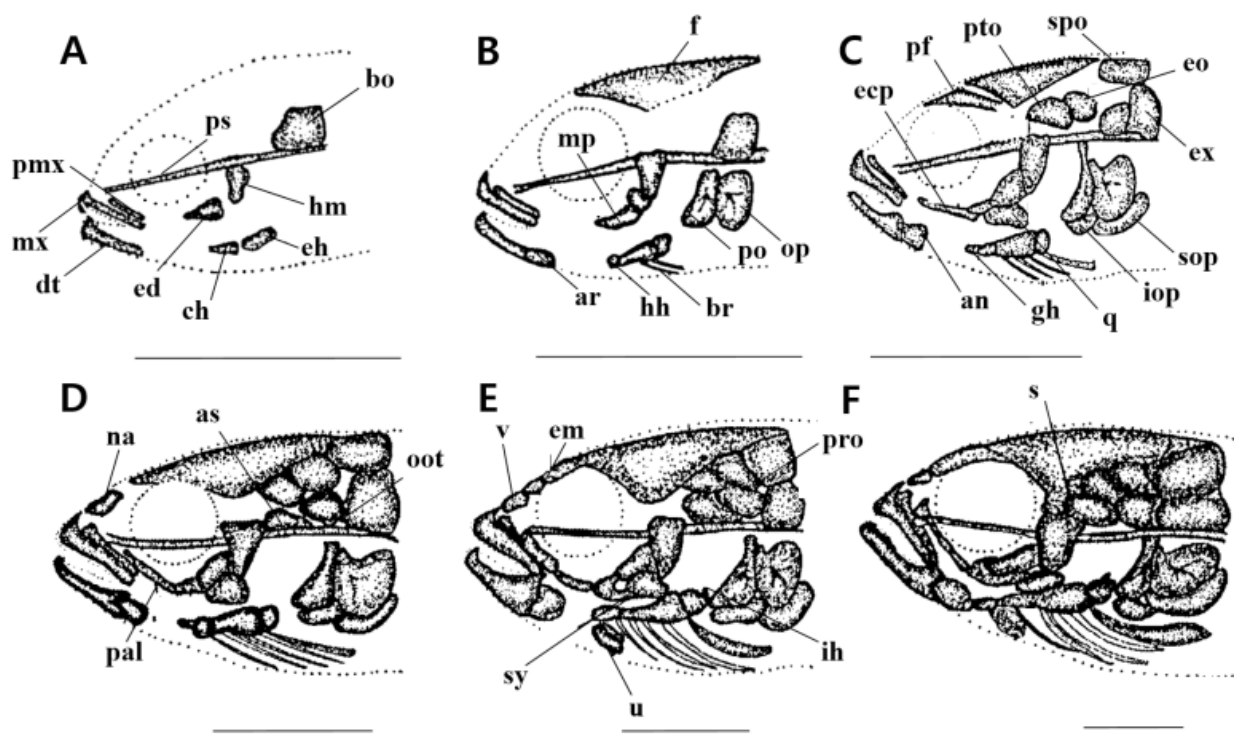

Fig. 1. Development of the cranium and visceral skeleton in Favonigobius gymnauchen. (A) 3 days after hatching $(\mathrm{DAH})$, mean $3.34 \mathrm{~mm}$, total length (TL), (B) $5 \mathrm{DAH}$, mean $3.96 \mathrm{~mm}$, TL, (C) $10 \mathrm{DAH}$, mean $5.15 \mathrm{~mm}$, TL, (D) $15 \mathrm{DAH}$, mean $6.21 \mathrm{~mm}$, TL, (E) $23 \mathrm{DAH}$, mean $8.87 \mathrm{~mm}$, TL, (F) $29 \mathrm{DAH}$, mean $10.2 \mathrm{~mm}$, TL. an, angular; ar, articular; as, alisphenoid; bo, basioccipital; br, branchiostegals; ch, ceratohyal; dt, dentary; ecp, ectopterygoid; ed, endopterygoid; eh, epihyal; em, ethmoid; eo, epiotic; ex, exoccipital; f, frontal; gh, glossohyal; hh, hypohyal; hm, hyomandibular; ih, interhyal; iop, interopercle $\mathrm{mp}$, metapterygoid; mx, maxillary; na, nasal; oot, opisthotic; op, opercle; pal, palatine; pf, prefrontal; pmx, premaxillary; po, preopercle; pro, prootic; ps, parasphenoid; pto, pterotic; q, quardrate; s, sphenotic; sop, subopercle; spo, supraoccipital; sy, symplectic; u, urohyal; v, vomer. Scale bars $=0.5 \mathrm{~mm}$, shown in Table 1 .

Table 1. The ossification process of cranium and visceral skeleton in Favonigobius gymnauchen

\begin{tabular}{|c|c|c|c|c|c|c|c|}
\hline & \multirow[b]{2}{*}{ Elements } & \multicolumn{6}{|c|}{ Total length $(\mathrm{mm})$, Days after hatching $(\mathrm{dAH})$} \\
\hline & & $\begin{array}{c}3.28-3.45 \\
\text { (3 dAH) }\end{array}$ & $\begin{array}{c}3.81-4.07 \\
(5 \mathrm{dAH})\end{array}$ & $\begin{array}{c}5.12-5.24 \\
(10 \mathrm{dAH})\end{array}$ & $\begin{array}{r}6.17-6.37 \\
(15 \mathrm{dAH})\end{array}$ & $\begin{array}{l}8.69-9.10 \\
(23 \mathrm{dAH})\end{array}$ & $\begin{array}{l}9.98-10.5 \\
(29 \mathrm{dAH})\end{array}$ \\
\hline \multirow[t]{14}{*}{ Cranium } & Parasphenoid & & & & & & \\
\hline & Prefrontal & & & & & & \\
\hline & Pterotic & & & & & & \\
\hline & Frontal & & & & & & \\
\hline & Basioccipital & & & & & & \\
\hline & Epiotic & & & & & & \\
\hline & Exoccipital & & & & & & \\
\hline & Nasal & & & & & & \\
\hline & Supraoccipital & & & & & & \\
\hline & Vomer & & & & & & \\
\hline & Alisphenoid & & & & & & \\
\hline & Sphenotic & & & & & & \\
\hline & Prootic & & & & & & \\
\hline & Lateral ethmoid & & & & & & \\
\hline \multirow[t]{2}{*}{ Upper jaw } & Maxillary & & & & & & \\
\hline & Premaxillary & & & & & & \\
\hline \multirow[t]{3}{*}{ Lower jaw } & Dentary & & & & & & \\
\hline & Articular & & & & & & \\
\hline & Angular & & & & & & \\
\hline
\end{tabular}


Table 1. Continued

\begin{tabular}{|c|c|c|c|c|c|c|c|}
\hline & \multirow[b]{2}{*}{ Elements } & \multicolumn{6}{|c|}{ Total length (mm), Days after hatching $(\mathrm{dAH})$} \\
\hline & & $\begin{array}{c}3.28-3.45 \\
(3 \mathrm{dAH})\end{array}$ & $\begin{array}{c}3.81-4.07 \\
(5 \mathrm{dAH})\end{array}$ & $\begin{array}{l}5.12-5.24 \\
(10 \mathrm{dAH})\end{array}$ & $\begin{array}{l}6.17-6.37 \\
(15 \mathrm{dAH})\end{array}$ & $\begin{array}{l}8.69-9.10 \\
(23 \mathrm{dAH})\end{array}$ & $\begin{array}{l}9.98-10.5 \\
(29 \mathrm{dAH})\end{array}$ \\
\hline \multirow[t]{6}{*}{ Hyoid arch } & Ceratohyal & & & & & & \\
\hline & Epihyal & & & & & & \\
\hline & Hypohyal & & & & & & \\
\hline & Branchiostegal rays & & & & & & \\
\hline & Glossohyal & & & & & & \\
\hline & Interhyal & & & & & & \\
\hline \multirow[t]{6}{*}{ Palate } & Hyomandibular & & & & & & \\
\hline & Qudrate & & & & & & \\
\hline & Metapterygoid & & & & & & \\
\hline & Palatine & & & & & & \\
\hline & Ectopterygoid & & & & & & \\
\hline & Endopterygoid & & & & & & \\
\hline \multirow[t]{4}{*}{ Opercular } & Opercle & & & & & & \\
\hline & Preopercle & & & & & & \\
\hline & Interopercle & & & & & & \\
\hline & Subopercle & & & & & & \\
\hline
\end{tabular}

\section{Vertebrae and caudal skeleton}

The mean TL of 3 DAH larvae was $3.34 \mathrm{~mm}$. In the vertebrae, three neural spines were ossified from the front of the abdominal vertebrae in the centrum form (Fig. 2A).

With a mean TL of $3.96 \mathrm{~mm}$ for $5 \mathrm{DAH}$ larvae, ten abdominal vertebrae and four caudal vertebrae began to ossify from the front of the vertebrae, and the number of neural spines increased to 13 (Fig. 2B).

The $10 \mathrm{DAH}$ larvae had a mean TL of $5.15 \mathrm{~mm}$, with the number of caudal vertebrae increasing to 15. The urostyle and two hypural bones in the lower part also began to ossify (Fig. 2C).

The 15 DAH larvae had a mean TL of $6.21 \mathrm{~mm}$, with the ossification of four interneural spines supporting the second dorsal fin and four hemalneural spines supporting the anal fin. At the lower part of the urostyle, one parhypural was ossified, and the number of hypural bones increased to three (Fig. 2D).

With a mean TL of $8.87 \mathrm{~mm}$ for $23 \mathrm{DAH}$ larvae, two interneural spines supporting the first dorsal fin and the interneural spines supporting the second dorsal fin increased to ten. The number of hemalneural spines supporting the anal fin increased to nine, two epural bones were ossified at the top of the urostyle, and the number of hypural bones increased to five (Fig. 2E).

The $29 \mathrm{DAH}$ juvenile had a mean TL of $10.2 \mathrm{~mm}$. The number of interneural spines in the first dorsal fin increased to six, $26(10+16)$ vertebrae were ossified, and the hypural bones were combined into three bone fragments $(1,2+3,4+5)$ (Fig. $2 \mathrm{~F})$.

\section{Pectoral girdle bone and pelvic girdle}

The $3 \mathrm{DAH}$ larvae had a mean TL of $3.34 \mathrm{~mm}$, and the line-shaped clavicle behind the gill started to be ossified in the pectoral girdle bone (Fig. 3A).

The 5 DAH larvae had a mean TL of $3.96 \mathrm{~mm}$, with supraclavicular ossification. The post temporal bone was ossified at the top, and the pelvic girdle began to ossify at the bottom of the clavicle (Fig. 3B). 


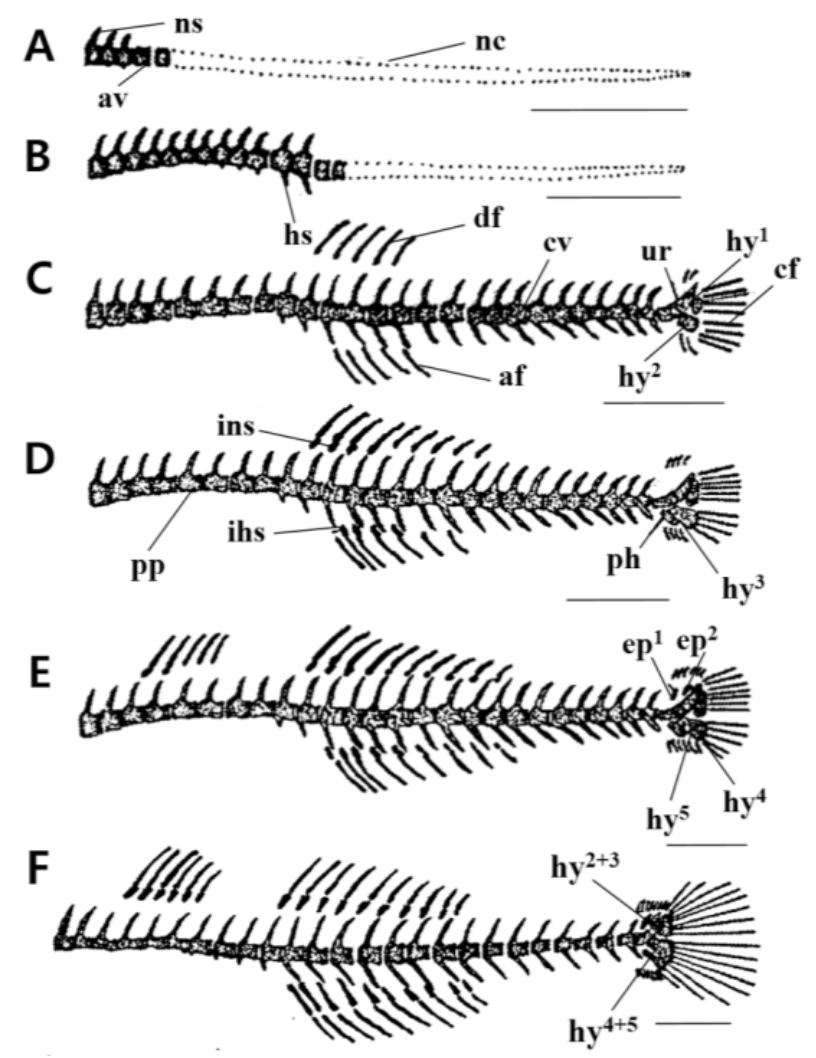

Fig. 2. Development of the vertebrae skeleton in Favonigobius gymnauchen. (A) $3 \mathrm{DAH}$, mean $3.34 \mathrm{~mm}$, TL, (B) $5 \mathrm{DAH}$, mean $3.96 \mathrm{~mm}$, TL, (C) $10 \mathrm{DAH}$, mean $5.15 \mathrm{~mm}$, TL, (D) $15 \mathrm{DAH}$, mean $6.21 \mathrm{~mm}$, TL, (E) $23 \mathrm{DAH}$, mean $8.87 \mathrm{~mm}$, TL, (F) $29 \mathrm{DAH}$, mean $10.2 \mathrm{~mm}$, TL. af, anal fin; av, abdominal vertebrae; cf, caudal fin; cv, caudal vertebrae; df, dorsal fin; ep, epural bone; hs, hemal spine; hy, hypural bone; ins, interhemal spine; ins, interneural spine; nc, notocord; ns, neural spine; ph, parhypural bone; pp, parapophysis; ur, urostyle bone. Scale bars $=0.5 \mathrm{~mm}$. TL, total length. $\mathrm{DAH}$, days after hatching, shown in Table 2.

Table 2. The ossification process of vertebrae and caudal skeleton and shoulder girdle bone in Tridentiger obscurus

\begin{tabular}{|c|c|c|c|c|c|c|c|}
\hline & \multirow[b]{2}{*}{ Elements } & \multicolumn{6}{|c|}{ Total length $(\mathrm{mm})$, Days after hatching $(\mathrm{dAH})$} \\
\hline & & $\begin{array}{c}3.28-3.45 \\
(3 \mathrm{dAH})\end{array}$ & $\begin{array}{c}3.81-4.07 \\
(5 \mathrm{dAH})\end{array}$ & $\begin{array}{l}5.12-5.24 \\
(10 \mathrm{dAH})\end{array}$ & $\begin{array}{l}6.17-6.37 \\
(15 \mathrm{dAH})\end{array}$ & $\begin{array}{l}8.69-9.10 \\
(23 \mathrm{dAH})\end{array}$ & $\begin{array}{l}9.98-10.5 \\
(29 \mathrm{dAH})\end{array}$ \\
\hline \multirow[t]{8}{*}{ Vertebrae } & Neural spine & & & & & & \\
\hline & Abdominal vertebra & & & & & & \\
\hline & Hemal spine & & & & & & \\
\hline & Caudal vertebra & & & & & & \\
\hline & Interneural spine & & & & & & \\
\hline & Interhemal spine & & & & & & \\
\hline & Parapophysis & & & & & & \\
\hline & Notocord & & & & & & \\
\hline \multirow[t]{4}{*}{ Caudal bone } & Parhypural & & & & & & \\
\hline & Hypural bone & & & & & & \\
\hline & Epural bone & & & & & & \\
\hline & Urostyle & & & & & & \\
\hline
\end{tabular}


Table 2. Continued

\begin{tabular}{|c|c|c|c|c|c|c|c|}
\hline & \multirow[b]{2}{*}{ Elements } & \multicolumn{6}{|c|}{ Total length $(\mathrm{mm})$, Days after hatching $(\mathrm{dAH})$} \\
\hline & & $\begin{array}{c}3.28-3.45 \\
(3 \mathrm{dAH})\end{array}$ & $\begin{array}{c}3.81-4.07 \\
(5 \mathrm{dAH})\end{array}$ & $\begin{array}{l}5.12-5.24 \\
(10 \mathrm{dAH})\end{array}$ & $\begin{array}{l}6.17-6.37 \\
(15 \mathrm{dAH})\end{array}$ & $\begin{array}{l}8.69-9.10 \\
(23 \mathrm{dAH})\end{array}$ & $\begin{array}{l}9.98-10.5 \\
(29 \mathrm{dAH})\end{array}$ \\
\hline \multirow[t]{7}{*}{$\begin{array}{l}\text { Shoulder } \\
\text { girdle bone }\end{array}$} & Clavicle & & & & & & \\
\hline & Post temporal & & & & & & \\
\hline & Supracleithrum & & & & & & \\
\hline & Scapula & & & & & & \\
\hline & Actinost & & & & & & \\
\hline & Coracoid & & & & & & \\
\hline & Pelvic girdle & & & & & & \\
\hline
\end{tabular}

A

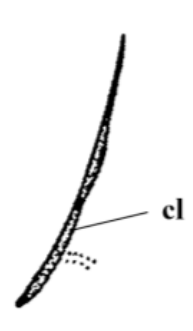

B

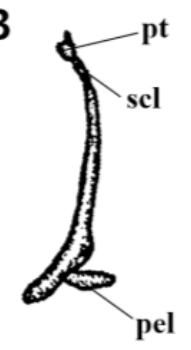

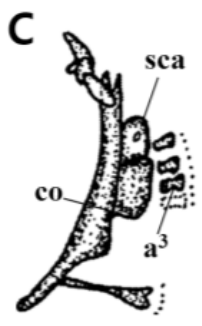

D

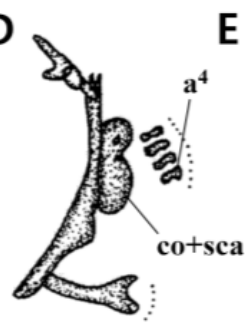

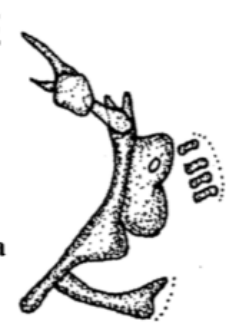

Fig. 3. Development of the pectoral girdle skeleton in Favonigobius gymnauchen. (A) 3 DAH, mean $3.45 \mathrm{~mm}$, TL, (B) $5 \mathrm{DAH}$, mean $4.07 \mathrm{~mm}$, TL, (C) $10 \mathrm{DAH}$, mean $5.20 \mathrm{~mm}$, TL, (D) $15 \mathrm{DAH}$, mean 6.46 $\mathrm{mm}$, TL, (E) $23 \mathrm{DAH}$, mean $8.47 \mathrm{~mm}$, TL. a, actinost; cl, clavicle; co, coracoid; pel, pelvic girdle; pt, posttemporal; sca, scapular; scl, supraclavicle. Scale bar $=0.5 \mathrm{~mm}$. TL, total length. $\mathrm{DAH}$, days after hatching, shown in Table 2.

With a mean TL of $5.15 \mathrm{~mm}$ for $10 \mathrm{DAH}$ larvae, the scapula and coracoid were ossified in the clavicle's back, and three actinosts were ossified in the lower part of the pectoral fin. The ventral fins began to develop in the pelvic girdle (Fig. 3C).

The 15 DAH larvae had a mean TL of $6.21 \mathrm{~mm}$, with the ossification of four actinost bones and the formation of rays at the back of the pelvic girdle (Fig. 3D).

The $23 \mathrm{DAH}$ juveniles had a mean TL of $8.87 \mathrm{~mm}$. The pectoral girdle's skeleton was completed as the scapula and coracoid were ossified. The pelvic girdle also fully supported the ventral fin as its ossification was completed (Fig. 3E).

\section{DISCUSSION}

The skeleton development of F. gymnauchen started from the three DAH with a mean TL of 3.34 $\mathrm{mm}$. The premaxillary, maxillary, and dentary bones were first developed to help with feeding. The hyomandibular and endopterygoid in the palate linked to the jaw skeleton, and the ceratohyal and epihyal in the hyoid arch were ossified to complete the skeleton of $29 \mathrm{DAH}$ juveniles with a mean TL of $10.2 \mathrm{~mm}$. As F. gymnauchen grew, the bones involved in its feeding and respiratory functions were preferentially ossified.

Luciogobius guttatus began to develop its skeleton at $11 \mathrm{DAH}$ with a mean TL of $5.50 \mathrm{~mm}$; the skeleton was completed at $47 \mathrm{DAH}$, with a mean TL of $13.4 \mathrm{~mm}$ (Kim et al., 1992). Luciogobius 
grandis started to develop its skeleton at three DAH with a mean TL of $4.01 \mathrm{~mm}$; its skeleton was completed at $36 \mathrm{DAH}$ with a mean TL of $12.2 \mathrm{~mm}$ (Yun et al., 2020). Tridentiger obscurus began to develop its skeleton at eight DAH with a mean TL of $8.62 \mathrm{~mm}$ and its skeleton was completed at $52 \mathrm{DAH}$ with a mean TL of $18.2 \mathrm{~mm}$ (Hwang et al., 2018). The skeleton development of $T$. trigonocephalus started at seven DAH with a mean TL of $4.44 \mathrm{~mm}$ and was completed at $40 \mathrm{DAH}$ with a mean TL of $13.3 \mathrm{~mm}$ (Han et al., 2018). Chaenogobius laevis started to develop its skeleton at 9-10 DAH with a mean TL of $6.00 \mathrm{~mm}$ and finished its skeleton development at $43 \mathrm{DAH}$ with a mean TL of $14.2 \mathrm{~mm}$ (Kim \& Han, 1989). F. gymnauchen completed the development of its skeleton earlier than these other species.

The cranium is an essential skeleton element for feeding and respiration, and is the part in which skeleton development preferentially occurs (Vandewalle et al., 1997), since the clavicle, which supports the sternohyoideus muscle, plays an essential role in mouth opening and feeding (Matsuoka, 1987; Wagemans \& Vandewalle, 1999).

The clavicle of F. gymnauchen started to develop in a thin line-shape at 3 DAH with a mean TL of $3.34 \mathrm{~mm}$, and developed in connection with the cranium at $23 \mathrm{DAH}$ with a mean TL of 8.87 $\mathrm{mm}$. The age and size when the clavicle became connected to the cranium in other species was 29 DAH with a mean TL of $11.4 \mathrm{~mm}$ for $L$. grandis (Yun et al., 2020), 25 DAH with a mean TL of $10.4 \mathrm{~mm}$ for C. laevis (Kim \& Han, 1989), $25 \mathrm{DAH}$ with a mean TL of $7.60 \mathrm{~mm}$ for L. guttatus (Kim et al., 1992), 28 DAH with a mean TL of 9.32 for T. trigonocephalus (Han et al., 2018), and 52 DAH with a mean TL of 18.3 for T. obscurus (Hwang et al., 2018). F. gymnauchen and L. guttatus (Kim et al., 1992) showed similarities in the connection period of the clavicle with the cranium and the mean TL values. In F. gymnauchen, the clavicle was connected to the cranium earlier than $L$. grandis (Yun et al., 2020), T. trigonocephalus (Han et al., 2018), and T. obscurus (Hwang et al., 2018). Chaenogobius laevis (Kim \& Han, 1989) showed a similar period for the connection but there was a difference in size, as it was smaller than F. gymnauchen.

The period when the cranium was connected to the clavicle in Gobiidae fish developed at the end of the postflexion larvae period. During this period, the pelvic girdle development led to a demersal life, and this development pattern is believed to be related to the swimming function for demersal life.

In F. gymnauchen's pterygiophore and vertebrae, the abdominal vertebrae began to develop together with the neural spine in a state of notochord with an incomplete skeleton in three DAH larvae (mean TL of $3.34 \mathrm{~mm}$ ). At $15 \mathrm{DAH}$ with a mean TL of $6.21 \mathrm{~mm}$, there were developments of a lateral process in the abdominal vertebrae, an interneural spine on the dorsal side, and an interhemal spine on the ventral side.

At $8 \mathrm{DAH}$ L. grandis with a mean TL of $4.87 \mathrm{~mm}$, the neural spine began to ossify in the state of the notochord; the interneural spine and interhemal spine were ossified after vertebrae and fin rays developed at $36 \mathrm{DAH}$ (with a mean TL of $12.2 \mathrm{~mm}$ ) (Yun et al., 2020).

In T. trigonocephalus (Han et al., 2018) and T. obscurus (Hwang et al., 2018), the neural spine was developed after the start of the ossification of the abdominal vertebrae. The interneural spine and interhemal spine were also ossified after the development of the vertebrae and fin rays.

The abdominal vertebrae and neural spine in F. gymnauchen were ossified simultaneously, completing the ossification of the pterygiophore after the development of the vertebrae. Such development patterns were the same as those of T. obscurus (Hwang et al., 2018) and T. trigonocephalus (Han et al., 2018). On the other hand, the neural spine was ossified earlier than the abdominal vertebrae in L. grandis (Yun et al., 2020), C. laevis (Kim \& Han, 1989), and L. guttatus (Kim et al., 1992). The earlier development of the fin rays than the vertebrae showed there were differences in development even within the family Gobiidae.

When the development of the vertebrae and fins was completed, the development of the 
pterygiophore seemed to be related to increasing the driving force in the fishes' swimming ability (Lee et al., 2001). In addition, in the early larval period of F. gymnauchen, larvae lacked the power to swim independently, but it seemed that feeding and swimming became active along with the development of the fin rays.

The development of vertebrae in F. gymnauchen proceeded from the anterior abdominal vertebrae to the posterior caudal vertebrae, and this developmental trend was the same in other Gobiidae species. The urostyle bone of $F$. gymnauchen developed with the ossification of the vertebrae. The urostyle bone was ossified before the ossification of the vertebrae in L. grandis (Yun et al., 2020). The urostyle bone was ossified after the ossification of the vertebrae in T. obscurus (Hwang et al., 2018) and T. trigonocephalus (Han et al., 2018). In other words, there were diverse developmental patterns depending on the species. When comparing the number of vertebrae, F. gymnauchen was most similar to T. obscurus (Hwang et al.,2018), and the number of vertebrae for the different species is as follows: $F$. gymnauchen was 26, L. grandis was 36 to 37 (Yun et al., 2020), T. obscurus was 25 to 27 (Hwang et al., 2018), C. laevis was 33 (Kim \& Han, 1989), and L. guttatus was 36 to 37 (Kim et al.,1992).

Despite having a similar number of vertebrae, F. gymnauchen and T. obscurus (Hwang et al., 2018) have distinct external morphological differences in the broodstock, but these are difficult to distinguish during the larval period. F. gymnauchen and T. obscurus (Hwang et al., 2018) showed similar characteristics in terms of the anus location of hatched larvae, number of myotomes, and melanophore distribution during the morphological development of the larvae and juveniles. However, this study confirmed differences in the development of the vertebrae and urostyle bone.

During the larval and juvenile period of Gobiidae fish, many species have similar external morphological characteristics, making it difficult to identify species. Therefore, anatomical information from larvae and juvenile fish are important data for distinguishing similar species, and further research in this area is required.

\section{REFEREANCES}

Chae BS, Song HB, Park JY, Cho KH (2019) A field guide to the freshwater fishes of Korea. LG Evergreen Foundation, Seoul, Korea.

Çoban D, Suzer C, Kamaci HO, Saka Ş, Firat K (2009) Early osteological development of the fins in the hatchery-reared red porgy, Pagrus pagrus (L. 1758).J Appl Ichthyol 25:26-32.

Han KH, Lee SH, Kim DY, Seo WI, Park JM (2018) Osteological development of the larvae and juvenile of chameleon goby, Tridentiger trigonocephalus. Korean J Ichthyol 30:137-143.

Huh SH, Kwak SN (1998) Feeding habits Favonigobius gymnauchen in the eelgrass (Zostera marina) bed in Kwangyang Bay.J Korean Fish Soc 31:372-379.

Hwang SY, Park JM, Lee SH, Han KH (2018) Osteological development of the larvae and juvenile of trident goby, Tridentiger obscurus. Dev Reprod 22:205-212.

Jin DS, Han KH, Park JW (2003) Spawning behavior and morphological development of larvae and juvenile of the nake-headed goby, Favonigobius gymnauchen (Bleeker). J Korean Fish Soc 36:136-143.

Kim HT, Kim HS, Park JY (2016) The anatomy and histology of the olfactory organ in the Korean sand goby Favonigobius gymnauchen (Pisces, Gobiidae). Korean J Ichthyol 28:28-34.

Kim YU, Han KH (1989) Early life history of the marine animals. 1. Egg development, larvae and juveniles of Chaenogobius laevis (Steindachner). Bull Korean Fish Soc 22:317-331.

Kim YU, Han KH, Kang CB, Ryu JW (1992) Early life history and spawning behavior of the gobiid fish, Luciogobius guttatus Gill. Korean J Ichthyol 4:1-13. 
Koumoundouros G, Gagliardi F, Divanach P, Boglione C, Cataudella S, Kentouri M (1997a) Normal and abnormal osteological development of caudal fin in Sparus aurata L. fry. Aquaculture 149:215-226.

Koumoundouros G, Oran G, Divanach P, Stefanakis S, Kentouri M (1997b) The opercular complex deformity in intensive gilthead sea bream (Sparus aurata L.) larviculture. Moment of apparition and description. Aquaculture 156:165-177.

Lee JS, Kim JW, Kang JC, Shin YK, Chin P (2000) Reroductive cycle and gonadal development of the naked-headed goby, Favonigobius gymnauchen (Teleostei : Gobiidae). J Korean Fish Soc 33:219-224.

Lee SJ, Kim YU, Han KH (2001) Osteological development of larvae and juveniles of Hyporhamphus sajori (Teleostei: Hemiramphidae). Korean J Ichthyol 13:173-180.

Lee CL (1990) Osteological study of the mudhopper, Periothalmus cantonensis (Perciformes, Gobiidae) from Korea. Korean J Zool 33:402-410.

Liu CH (2001) Early osteological development of the yellow tail Seriola dumerili (Pisces: Carangidae). Zool Stud 40:289-298.

Matsuoka M (1987) Development of the skeletal tissues and skeletal muscles in the red sea bream. Bull Seikai Red Fish Res Lab 65:1-14.

Mook D (1977) Larval and osteological development of the sheepshead, Archosargus probatocephalus (Pisces: Sparidae). Copeia 1977:126-133.

Nelson JS, Grande TC, Wilson MVH (2016) Fishs of the World. 5th ed. John Wiley \& Sons, Hoboken, NJ.

Potthoff T, Kelley S, Collins LA (1988) Osteological development of the red snapper, Lutjanus campechanus (Lutjanidae). Bull Mar Sci 43:1-40.

Potthoff T, Kelly S, Saksena V, Moe M, Young F (1987) Description of larval and juvenile damselfish Microspathodon chrysurus, Pomacentridae, and their osteological development. Bull Mar Sci 40:330-375.

Potthoff T, Tellock JA (1993) Osteological development of the snook, Centropomus undecimalis (Teleostei, Centropomidae). Bull Mar Sci 52:669-716.

Sfakianakis DG, Koumoundouros G, Divanach P, Kentouri M (2004) Osteological development of the vertebral column and of the fins in Pagellus erytbrinus (L. 1758). Temperature effect on the developmental plasticity and morpho-anatomical abnormalities. Aquaculture 232:407-424.

Vandewalle P, Gluckmann I, Baras E, Huriaux F, Focant B (1997) Postembryonic development of the cephalic region in Heterobranchus longifilis.J Fish Biol 50:227-253.

Yun SM, Park JM, Han KH (2020) Osteological development of the larvae and juvenile of Luciogobius grandis (Pisces: Gobiidae). Dev Reprod 24:125-133.

Wagemans F, Vandewalle P (1999) Development of the cartilaginous skull in Solea solea: Trends in pleuronectiforms. Ann Sci Nat Zool Biol Anim 20:39-52.

Walker MB, Kimmel CB (2007) A two-color acid-free cartilage and bone stain for zebrafish larvae. Biotech Histochem 82:23-28. 
